\title{
Moderating effect of social capital on community empowerment and economic well-being
}

\section{Sarjiyanto}

Department of Economics, Faculty of Economics \& Business, Universitas Sebelas Maret, Surakarta, Indonesia

Correspondence author email: masyanto@staff.uns.ac.id

\begin{tabular}{|l|l|l|l|l|}
\hline DOI: & Received: & Revised: & Accepted: & Published: \\
10.22437/ppd.v9i6.15325 & 01.11 .2021 & 13.02 .2022 & 25.02 .2022 & 28.02 .2022 \\
\hline
\end{tabular}

\begin{abstract}
Improving community economic well-being based on community empowerment plays an important role in rural development. This study aims to determine the ability of social enterprises in Indonesia (Village-Owned Enterprises/BUMDes) to improve the community's economic well-being through empowerment programs and the role of social capital in rural community development. At social conditions at the basic level, very little attention is paid to the development of deprived communities. Starting from the experience of rural community economic empowerment programs through the establishment of Village-Owned Enterprises (BUMDes) in Indonesia, this study will test three hypotheses: (1) whether there is an effect between community empowerment and the economic well-being of rural communities; (2) is there an effect between social capital and the economic well-being of rural communities; and (3) is the effect between community empowerment and economic well-being mediated by social capital? Multiple regression analysis is used to examine the effect between community empowerment and community economic well-being. This analysis highlights the central role of social capital in mediating the effect between community empowerment and economic well-being. Community empowerment is significantly related to social capital. These effects between social capital, community empowerment, and economic well-being apply to theories and measures of rural community empowerment.
\end{abstract}

Keywords: Economic well-being, Rural community, Social capital

JEL Classification: I38, M21, O18

\section{INTRODUCTION}

Social capital can be a useful concept for practitioners, researchers, and policymakers in bringing about the lost social sense. The most important feature of social capital is that trust, norms, and reciprocal effects arise from repeated and regular interactions limited by space and time in a community (Kay, 2005). In many communities, social capital with an interactional approach to community development can be a useful alternative (Bridger \& Alter, 2006)). In line with Theodori (2008), like society, the element of sustainable community development is social interaction. Therefore, the success of the rural community development process relies heavily on the willful actions of people in local meetings and social interactions to solve their local 
problems, improve their quality of life, and shape their future. Trigillia (2001) states that social capital is an important aspect of local economic development.

Social capital is the ability of actors to benefit from relying on membership in social networks and other social structures (Portes, 1998). Meanwhile, according to Woolcock (1998), social capital is the level of social cohesion in society. It refers to the process between people building networks, norms, and social trust and facilitating coordination and cooperation. Fukuyama (1995) conceptualizes social capital as an informal norm that encourages mutually beneficial cooperation. Putnam (1993) defines social capital as a collection of horizontal associations between people that affect the productivity of local communities. Associations, including citizen engagement networks and social norms. Lang \& Hornburg (1998) argue that social capital generally refers to mutual trust in society, norms, and networks that society can use to solve common problems. Putnam (2000) further suggests that social capital is a stock of social beliefs, networks, and values that people can take to improve their livelihoods and pursue common goals.

The concept of social capital needs to be understood in terms of systems and aspects of relations. Criticism of social capital originates from the understanding of the concept of social capital, which only focuses on aspects of relations as written by Harriss (2002). Esser (2007) has reminded that social capital also includes aspects of the system. It is possible because social capital as social relations, shared beliefs, and norms in development is about what the community knows and how people know, discuss, and build arguments (Berkes, 2009). Most of the work on social capital arguably focuses primarily on resources as capital but has demonstrated the importance of all kinds of social association in negotiating the ups and downs of daily life and with subjective assessments of well-being (Helliwell \& Putnam, 2004).

Social capital is a social resource that can be seen as an investment in obtaining new resources in society. Therefore, social capital is believed to be one of the key components in mobilizing togetherness, mobility of ideas, mutual trust, and mutual benefit to achieve mutual progress, especially in the development of rural communities. Fukuyama (1999) states that social capital plays a very important role in the functioning and strengthening of society. On this basis, social capital can refer to norms or networks that allow people to take collective action (Fine \& Lapavitsas, 2004). It should be remembered that social capital in question should not be separated from the capital in a literal economic sense and lose power relations (DeFilippis, 2001). Social capital is a condition that must be met to develop rural communities. So to evaluate the success of rural community development, social capital is considered a representation of the success of rural community development in improving the quality of life.

The empowerment of rural communities can be realized through active community participation facilitated by empowerment actors. The ultimate goal of the rural community empowerment process is to make community members independent to improve their family's standard of living and optimize their resources. According to Sarjiyanto (2017), in a broader sense, community empowerment is a process to facilitate and encourage people to position themselves proportionally and become the main actors in utilizing their strategic environment to achieve long-term sustainability. Empowerment is a value orientation for working in society and a theoretical for understanding the processes and consequences of efforts to control and influence decisions that affect a person's life, organizational functions, and the quality of people's lives (Zimmerman, 2000). Empowerment can have a different meaning in a given context in other contexts. In addition, as long as it can be developed in a study, it may 
not be suitable for other contexts. It must be culturally appropriate to measure the increasing strength of community members (Hombrados-Mendieta \& Gómez-Jacinto, 2001).

Community Empowerment is an effort to develop the potential and power of society by encouraging, motivating, and raising awareness of its potential and striving to develop it. Based on Zimmerman (2000), empowerment theory suggests ways to measure constructs in different contexts, study the empowerment process, and distinguish empowerment from other constructs, such as self-esteem, self-efficacy, or locus of control. A universal measure of empowerment may not be possible, but comparative research reveals that some empowerment indicators are more universal than others (Malhotra et al. 2002).

Labonte \& Laverack (2001) define a capacity building as a form of increasing community empowerment and following up on issues related to community members. Community capacity has also been described as the combined influence of community commitments, resources, and skills, increasing community power and addressing local community problems. Civil society participation refers to society's individual and collective actions to identify and address local problems of concern to society (Peterson \& Hughey, 2004). Butterfoss \& Kegler (2002) explains that members' previous experiences with social problems will increase the level of commitment of each member.

The level of member participation varies in intensity, depending on the type of community coalition. Brakel et al. (2006) categorized these participants as active, occasional, and supportive community development programs. They suggest that flexible participation is needed when volunteering and working for social change in society. Cameron et al. (2010) observed that the core community group should consist of members committed to the same or similar problems and can solve problems, as in the organization of Village-Owned Enterprises (BUMDes). Meanwhile, Khwaja (2004) explains that organizational participation can be an important means of encouraging decision-makers to take community participation seriously and integrate their decisions according to community needs. Soler et al. (2014), the Participatory Empowerment Process has been relevant for the people involved: (a) it has made it possible to create a strong steering group; (b) better self-knowledge; (c) to identify evaluation tools and group activities; and finally, (d) provides visibility into the work being done and the forces behind community development projects.

Helping communities to gain expertise, confidence, and control over events and local development, as argued by Bebbington et al. (2006), is an example of community empowerment. Community empowerment is one of the advances most often associated with psychological and social development. It thus has become the center of attention for local development engagements and programs driven by local communities (Mansuri \& Rao 2003). Abundant literature is available on community involvement and participation in rural studies (Mark 1998; David 1999; Ruth 2000; Jiggins 2007; Sally 2008; Berkhout et al. 2010; Steyaert \& Beeton \& Lynch. 2012), but the effect between community empowerment and social relations as a form of social capital is still limited to be investigated. Therefore, the empowerment process consists in recognizing the benefits that individuals and communities derive from the social interactions of community members in planning activities and decision-making operations, enhancing their abilities (Narayan \& Shah 2000). This study is important to see whether there is a significant effect between community empowerment and its various dimensions on improving community well-being, especially on economic well-being in rural 
communities as objects of empowerment.

Rural community development aims to improve well-being by strengthening communities consistent with the core principles: collective action, empowerment, social justice, participation, equality, anti-discrimination (Winterton et al., 2014). According to Mansari \& Roa (2004), newer community-based development must be increased because it is the fastest-growing mechanism for assisting development. Communitydriven development is an umbrella term for projects that actively involve community members in their design and management. And community-based development highlight community-driven development projects in which rural communities have direct control over key project decisions, as in the working mechanism of VillageOwned Enterprises (BUMDes). The success of rural community development, Gallardo (2015) provides a framework for the concept that economic development is often associated with two objectives: (1) creating jobs and wealth and (2) increasing community well-being. Community as a mechanism to address well-being at individual, social, and ecological rankings (Larson et al., 2015). Wiseman \& Brasher (2008) states that people's well-being is a combination of social, economic, environmental, cultural, and political conditions identified by individuals and their communities as important for developing and fulfilling their potential well-being. Raphael et al. (2001) argued that the community well-being approach focuses on understanding community members about what makes them good or bad. Rural well-being directs attention to how the lives of individuals determine these indicators by considering whether and how basic human needs are met in society.

McCrea et al. (2014) rural communities strive to build prosperity and resilience in their local areas. The public well-being assessment aims to measure what is being experienced to take action in the public and social sectors and private partners to achieve the desired goals. However, since public well-being is a relatively new idea in social science, it still lacks a theoretical structure for explanatory purposes (Sung \& Phillips, 2018). Well-being is also a double concept, depending on who uses the term (Gasper, 2010). Here, it is aligned with Atkinson (2013), who uses well-being to imagine the outcome of the complexity of effects. The countryside is often described as a homogeneous space, as reflected in the place-based policies enforced at the localbased level (Ray, 2000). At the same time, the indicators of well-being in the economic dimension are economic conditions based on data on; economic conditions, how adequate production and consumption are, business conditions, cost of living, income, and distribution (Attwood, 2013 and Musa et al., 2019).

Law No. 6/2014 on Villages provides legal protection for Village-Owned Enterprises as economic actors who manage the collective potential of villages to improve the well-being of village communities. Village-owned enterprises are one of the pillars of economic activity in the village that function as social and commercial institutions. Village-owned enterprises are social institutions that side with the community's interests by contributing to social services. Meanwhile, as a commercial institution, it aims to profit by offering local resources (goods and services) to the market (Law No. 32/2014). BUMDes can function as a mediator between community empowerment and individual change. With community empowerment through BUMDes in several villages in Indonesia, it is hoped to accelerate the improvement of rural communities' quality of life and well-being.

Empowerment is a process of increasing personal, interpersonal, or political power so that individuals, families, and communities can take action to improve their situation (Gutierrez, 1995). Community-based and grassroots organizations are 
considered key actors in individual and collective efforts to change attitudes. One of the organizations in rural areas to increase well-being and quality of life is Village-Owned Enterprises (BUMDes). Indonesia has implemented a new approach to encourage and drive the rural economy by establishing economic institutions managed by rural communities through BUMDes. The notion of community empowerment, in all formulas, has become an increasingly important component of urban and rural development policies (Adamson 2010; Phillips et al., 2010). The term empowerment becomes meaningful when the private agency impacts society (Soler et al., 2014).

Meanwhile, Dhesi (2000) social capital has become an important component of many community development strategies. BUMDes that are successful are certainly those that can forge synergistic cooperation both within and within its members, including forging social effects outside the community. Following the concept of Dale \& Newman (2008), social capital is a necessary condition for realizing sustainable community development because it increases ties that increase access to resources outside the community. So based on this conception through this research, it will be explored to what extent the role of social capital as a binder in rural communities, empowerment as a capacity building process in rural communities, and its effect to the level of community well-being as the goal of rural community development can be achieved.

Community well-being has been linked to other policy objectives such as social capital, community resilience, capacity, sustainability, and development (Dabson, 2011; Goldenberg, 2008; Randall, 2010). Through this research, the economic well-being of rural communities due to the economic development process through the VillageOwned Enterprises (BUMDes) program will be linked to community empowerment and social capital. So in this study, three research hypotheses will be answered and will be statistically tested to see the effect of the variables and the theoretical implications for the rural community development. The three hypotheses are compiled based on problems and empirical considerations as well as in-depth theoretical studies, namely:

Hypothesis 1: Community empowerment has a positive effect on the economic wellbeing of the community

Hypothesis 2: Social capital has a positive effect on the economic well-being of the community

Hypothesis 3: Social capital moderates the effect of community empowerment on community well-being

Based on the theoretical background and research hypothesis, the conceptual research can be described in Figure 1.

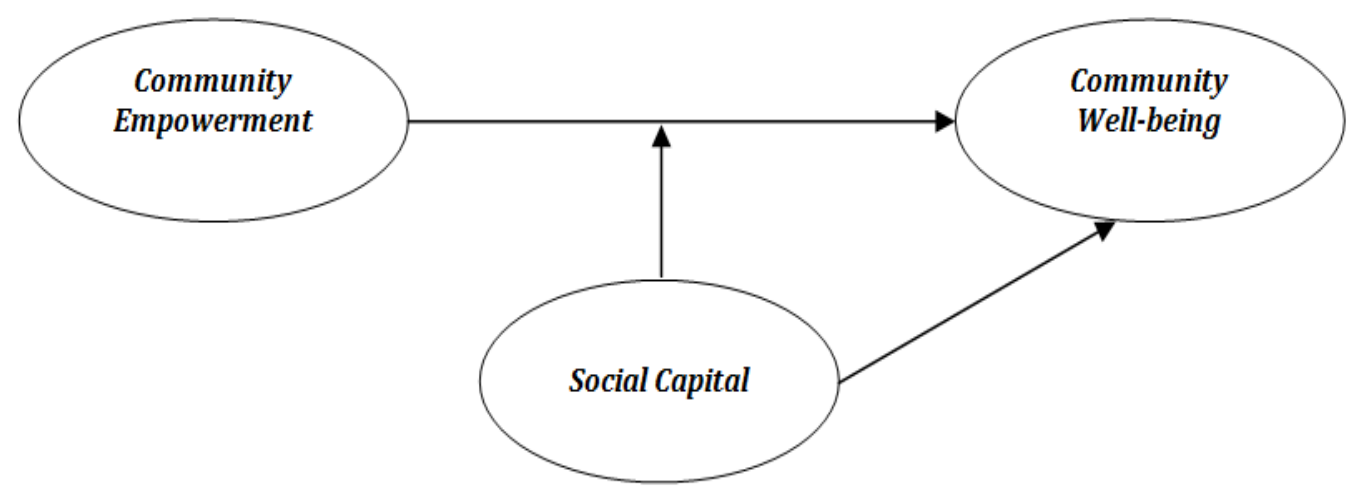

Graph 1. The conceptual research 


\section{METHODS}

\section{Data collection, sampling techniques, and samples}

Data collection was carried out by survey using a questionnaire. The sample in this research is BUMDes management in industrial areas and rural areas. The sampling technique used purposive sampling. Members of the population who can meet the requirements determined by the researcher, who have been active members or administrators for more than three years and are willing to be the sample, will be selected as samples in the study. The distribution of the samples in this study came from 6 districts across provinces, namely Central Java and East Java. Of the six districts the sample originates, 3 BUMDes represent industrial areas, and 3 BUMDes represent rural areas. From 300 questionnaires distributed to respondents, 249 respondents gave complete and feasible answers for data analysis. Thus, the response rate in this study was $83 \%$.

\section{Variable measurement}

To measure each variable, set indicators through a list of questions that respondents must answer using a Likert scale (1-7). The Social Capital variable uses a contour that has been built by Onyx \& Bullen (2000) by looking at indicators; participation in the local community (sc1), proactivity in a social context (sc2), feeling of trust and safety ( $\mathrm{sc3}$ ), neighborhood connection (sc4), tolerance of diversity (sc5), and value of life (sc6) to measure social capital in the community. The Community Empowerment variable uses the constructs of Ahmad \& Talib (2014) and Soler et al. (2014) by looking at indicators; community capacity building (ce1), community participation (ce2), community access to information (ce3), community identity (ce4), community knowledge (ce5), and community organization (ce6). Meanwhile, the community well-being variable in this study is focused on economic well-being using the construct of Musa et al. (2019) by measuring indicators in the subjective well-being dimension, namely; family income (cwb1), cost of living (cwb2), residents income gap (cwb3), accessibility (cwb4), access to job /employment (cwb5), business activity (cwb6).

\section{Data analysis}

Descriptive analysis is used to analyze data to describe or describe the data that has been collected. Of the 249 respondents participating in the survey, $69 \%$ were male, and $31 \%$ were female. Based on education level, the majority of graduates from elementary to junior high school (47.6\%), followed by middle and above level $(43 \%)$ and tertiary education $(5.6 \%)$. It was furthermore tested the validity, reliability, and hypothesis testing. The validity test was carried out by factor analysis using the KMO approach, the Measure of Sampling Adequacy, and the anti-image correlation value. At the same time, the reliability test is measured by looking at the Cronbach's Alpha value. Hypothesis testing in this study was carried out using hierarchical regression analysis techniques to determine whether to reject or accept the proposed hypothesis. Hierarchical regression analysis is used to examine the effect of community empowerment and social capital on community well-being and then examine the effect of the interaction between community empowerment and social capital on community well-being. The hierarchical regression formula in this study is as follows: 


$$
Y=\beta_{0}+\beta_{1} X_{1}+\beta_{2} X_{2}+\beta_{3}\left(X_{1} * X_{2}\right)+e
$$

\begin{tabular}{|c|c|}
\hline Notes: & \\
\hline Y & = community well-being \\
\hline $\mathrm{X} 1$ & $=$ community empowerment \\
\hline $\mathrm{X} 2$ & $=$ social capital \\
\hline$\beta 0$ & $=$ Intercept \\
\hline$\beta 1, \beta 2, \beta 3$ & $=$ coefficient of each variable \\
\hline
\end{tabular}

\section{RESULTS AND DISCUSSION}

The validity test in this study was carried out by factor analysis using the KMO approach, Measure of Sampling Adequacy, and anti-image correlation values. The validity test shows that all indicators in the variables in this study are declared valid and worthy to be continued in the next analysis.

Based on Table 1 shows that the KMO MSA value is 0.739 (> 0.5) with a significance level of 0.000 , so it can be concluded that the variables in the study as a whole are declared valid. Meanwhile, the anti-image correlation matrix presents the correlation between indicators in the variables used.

Table 1. Value of KMO MSA, Chi-Square, Degree of Freedom, and Level of Significance

\begin{tabular}{lll}
\hline Kaiser-Meyer-Olkin Measure of Sampling Adequacy. & .739 \\
Bartlett's Test of Sphericity & Approx. Chi-Square & 3681.473 \\
& df & 153 \\
& Sig. & .000 \\
\hline
\end{tabular}

Meanwhile, Table 2 shows that the correlation value between indicators in the variable shows the value that meets the minimum criteria for the KMO MSA value of 0.5 . Thus all indicators in the variables in this study were declared valid.

Table 2. Anti Image Correlation

\begin{tabular}{|c|c|c|c|c|c|c|c|c|c|c|c|c|c|c|c|c|c|}
\hline & & & & & 5 & & & 2 & c3 & 4 & c5 & c6 & & & & & \\
\hline ce1 & $.759^{\mathrm{a}}$ & 62 & & & & & .029 & & & & & & & & & & 105 \\
\hline & & & & & & & & & & & & & & & & & \\
\hline & & & & & & & & & & & & & & & & & \\
\hline & -.0 & & & & & & & .054 & .266 & -.431 & & & & & & & \\
\hline & .125 & & & & & & & & & .349 & & .097 & & & & & \\
\hline & & & & & & & & & & & & & & & & & \\
\hline & & & & & & & & & & & & & & & & & \\
\hline & -.08 & & & & & & -. & .74 & & -.258 & & & & & & & \\
\hline & & & & & & & & & & & & & & & & & $2-.13$ \\
\hline & & & & & & & .0 & -.25 & & $.596^{\mathrm{a}}$ & & & & & & & \\
\hline & .05 & & & & & & & .08 & & -.462 & & -.40 & & & & & -.11 \\
\hline & .24 & & & & & & & & & & & & & & & & -.0 \\
\hline & & & & & & & & & & & & & & & & & \\
\hline & -.08 & & & & & & & .1 & & -.173 & & & & & & & \\
\hline & .099 & & & -.050 & -.0 & & -.06 & -.005 & -.07 & & & -.133 & & & & & $3-.3$ \\
\hline & .08 & & & & & & & -.1 & & -.11 & & & & & & & \\
\hline & -.10 & & & & & & -.02 & & & -.09 & & & & & & & \\
\hline cwb6 & .164 & -.029 & -.046 & -.108 & .200 & -.228 & .186 & -.049 & -.157 & .125 & .126 & -.039 & -.172 & .024 & -.353 & -.182 & -.518 \\
\hline
\end{tabular}

As for the reliability test in the study using the Cronbach Alpha value, Cronbach's Alpha value of $0.712(>0.6)$ indicates that the indicators used in the variables in this study are declared reliable, as in Table 3. Thus, the data collected from this study is suitable for processing at a later stage. 
Table 3. Reliability test results

\begin{tabular}{ccc}
\hline Cronbach's Alpha & Cronbach's Alpha Based on Standardized Items & N of Items \\
\hline .712 & .723 & 18 \\
\hline
\end{tabular}

The next stage is data analysis in this study using multiple regression analysis. The results of multiple regression analysis are presented in Table 4 .

Table 4. Results of data analysis with multiple regression

\begin{tabular}{lrrrrrr}
\hline \multirow{2}{*}{ Variable } & \multicolumn{3}{c}{ Model 1 } & \multicolumn{3}{c}{ Model 2 } \\
\cline { 2 - 7 } & Coeff. $(\beta)$ & t- stat & Sig. Coeff. $(\beta)$ & t- stat. & Sig. \\
\hline Constanta & 0.334 & 4.122 & $0.000^{*}$ & -0.205 & -0.511 & 0.610 \\
Community Empowerment (CE) & 0.920 & 44.634 & $0.000^{*}$ & 0.404 & 3.911 & $0.000^{*}$ \\
Social Capital (SC) & - & - & - & 0.728 & 6.519 & $0.000^{*}$ \\
$\mathrm{CE} \rightarrow \mathrm{SC}$ & - & - & - & -0.018 & -0.694 & 0.488 \\
\hline $\mathrm{R}^{2}$ & \multicolumn{3}{c}{0.890} & & & 0.956 \\
\hline
\end{tabular}

Dependent Variable: Community Well Being

*) Significant level 0,01

The results of data analysis using multiple linear regression indicate that community empowerment has a positive effect on community well-being $(0,920$; 44,634). These findings support hypothesis 1, which proposes that community empowerment positively affects the community's economic well-being. Social Capital also positively affects community well-being $(0.728 ; 6,519)$. This finding clouded hypothesis 2 that social capital has a positive effect on the economic well-being of society. In connection with the role of social capital as moderator, in this study, there was no moderating effect of social capital in adhering to community empowerment in community well-being $(-0.018 ;-0.694)$. This finding does not support hypothesis 3 , which is proposed that social capital moderates the influence of community empowerment on community well-being.

This study attempts to better understand rural development, the role of social capital in the community empowerment process, and its impact on community wellbeing. This study examines the contribution of social capital and empowerment to community well-being in rural community development. By selecting participants from community members who are already members of one of the community empowerment programs through BUMDes, this study finds several findings that expand the literature on rural development, particularly those related to empowerment and the role of social capital in rural community development. This study found that community empowerment affects the level of well-being. These results support the hypothesis that empowerment has a positive effect on the economic well-being of society. These results are consistent with research conducted by Theodori (2005), which found that community development is the concept of community interaction which can be seen as a process of building, strengthening, and maintaining community unity within the framework of empowerment. This meeting supports the concept of Green \& Haines (2002) and Phillips \& Pittman (2009) that community development is a planned effort to generate assets through increasing the capacity of communities to improve their wellbeing. These assets include several forms of public capital: physical, financial, environmental, human, and social.

Regarding the role of social capital, this study shows that social capital positively and significantly affects the well-being of society in rural community development. 
These results support the hypothesis that social capital positively affects community well-being. In other words, the effect of collectivism and high social cohesion strengthens community well-being in the development of rural communities. High collectivist culture is characterized by strong ties and social interactions within a group. This culture means that group interests are above personal interests, and common goals are considered more important than individual achievement.

Meanwhile, the findings of this study state that social capital does not moderate the effect between community empowerment and community well-being in rural community development. This condition results in an orientation to the role of social capital as an active empowerment partner that contributes to prosperity. The addition of social capital strengthens the ability to explain community well-being.

In general, this study proves that together the aspects of empowerment and social capital affect community well-being in the rural community development. This study shows that social capital positively and significantly affects community well-being but does not moderate the effect between empowerment and well-being in rural community development. This finding confirms the concept of the role of social capital in development by DeFilippis (2001) that social capital should not be separated from the capital in a literal economic sense and lose power relations. Social capital must be inspired by the assumption that social networks are mutually beneficial because individuals' benefits, interests, and benefits are identical to those of groups. Strong social capital, organizations, or community groups can more easily determine what they want to do and how to manage other capital needs. Social capital cannot replace the more significant forms of capital, but it can help. The findings of this study are also in line with Labonte's (1999) study. Social capital and community development are many national interventions used to prevent market imbalances.

\section{CONCLUSIONS AND RECOMMENDATIONS}

\section{Conclusions}

Improving community economic welfare based on community empowerment plays an important role in rural development. Departing from the experience of rural community economic empowerment programs through the establishment of Village Owned Enterprises (BUMDes) in Indonesia, multiple regression analysis was used to examine the effect of community empowerment on community economic welfare. The results of data analysis using multiple linear regression indicate that community empowerment has a positive effect on community welfare. This finding supports the theory that community empowerment positively affects the community's economic welfare. Social Capital also has a positive effect on people's welfare. This finding hypothesizes that social capital positively affects the community's economic welfare. Regarding the role of social capital as a moderator, in this study, there was no moderating effect of social capital in participating in community empowerment in community welfare. This finding does not support the proposed hypothesis that social capital moderates the effect of community empowerment on people's welfare.

Community empowerment is closely related to social capital. The effect between social capital, community empowerment, and economic well-being applies to theories and measures of rural community empowerment. This study tries to better understand 
rural development, the role of social capital in community empowerment, and community welfare. This study examines the contribution of social capital and empowerment to community welfare in rural community development. This study finds several findings that need to be developed regarding rural development, especially those related to empowerment and the role of social capital in the development of rural communities. This study found that community empowerment affected the level of welfare.

This research proves that together the aspects of empowerment and social capital affect the community's welfare in the development of rural communities. This study shows that social capital has a positive and significant effect on community welfare but does not moderate the influence between empowerment and welfare in rural community development. The findings of this study also prove that social capital and community development are among the many national interventions used to prevent market balance. Social capital can be a separate independent variable useful for practitioners, researchers, and policy makers and a sense of lost community.

\section{Recommendations}

Based on the study results, the role of social capital does not provide a moderating effect between economic welfare and community empowerment. However, partially and simultaneously, the role of social capital and community empowerment positively affects the community's economic welfare. So the recommendations from this study are; every empowerment program that is carried out aims to improve economic welfare and the need to empower non-economically, such as social capital in the community. Together, social capital can maintain the purpose of community empowerment programs, which ultimately is to increase economic and social welfare sustainability.

So that although the role of social capital does not directly affect economic welfare, the presence of social capital is very much needed in every community empowerment agenda. Further researchers need to conduct in-depth studies on the relationship of social capital, community empowerment, and economic welfare with qualitative and quantitative approaches.

\section{REFERENCES}

Adamson, D. (2010). Community empowerment: Identifying the barriers to " $p u r p o s e f u l "$ citizen participation. International Journal of Sociology and Social policy, 30(3/4), 114-126.

Ahmad, M.S., \& Abu Talib, N.B. (2014). Analysis of Community Empowerment on Projects Sustainability: Moderating Role of Sense of Community. Social Indicators Research, 129(3), 1039-1056.

Atkinson, S. (2013). Beyond components of well-being: The effects of relational and situated assemblage. Topoi, 32, 137-144.

Attwood, H.E. (2013) The influence of quality-of-life research on quality-of-life: CLIQ case studies from KwaZulu-Natal, South Africa. Community quality of life indicators, (6) 1-18.

Bebbington, A., Guggenheim, S., \& Woolcock, M. (2006). Concepts: Their contexts and their consequences. In Anthony Bebbington, Scott Guggenheim, Michael 
Woolcock, \& Elizabeth A. Olson (Eds.), The search for empowerment: Social capital as idea and practice at the World Bank (pp. 261-287). Bloomfield: Kumarian Press.

Beeton, R.J.S., \& Lynch, A.J.J. (2012). Most of nature: A framework to resolve the twin dilemmas of the decline of nature and rural communities. Environmental Science \& Policy, 23, 45-56.

Berkhout, F., Verbong, G., Wieczorek, A.J., Raven, R., Lebel, L., \& Bai, X. (2010). Sustainability experiments in Asia: Innovations shaping alternative development pathways? Environmental Science \& Policy, 13(4), 261-271.

Berkes, F. (2009). Evolution of Co-management: Role of knowledge Generation, Bridging Organizations and Social Learning. Journal of Environmental Management, 90(5), 1692-1702.

Brakel, D.W.H.V., Anderson, A.M., Mutatkar, R.K., Bakirtzief, Z., Nicholls, P.G., Raju, M.S. (2006). The participation scale: Measuring a key concept in public health. Disability and Rehabilitation, 28(4), 193-203.

Bridger, J.C., \& Alter, T.R., 2006, Place Community Development and Social Capital. Community Development Journal, 37(1), 5-18.

Butterfoss, F.D., \& Kegler, M.C. (2002). Toward a comprehensive understanding of community coalitions: Moving from practice to theory, San Francisco: JosseyBass.

Cameron, C., Ghosh, S., Eaton, S.L., \& Caballes, D.A., 2010, Facilitating communities in designing and using their own community health impact assessment tool. Environmental Impact Assessment Review, 43(1), 1-5.

Dabson, B. (2011). Rural regional innovation: A response to metropolitan-framed place based thinking in the United States, Australasian Journal of Regional Studies, 17(1), 7-21.

Dale, A., \& Newman, L. (2008). Social Capital: a Necessary and Sufficient Condition for Sustainable Community Development? Community Development Journal, 45(1), 5-21.

David, S, (1999). Issues of integration, participation and empowerment in rural development: The case of LEADER in the Republic of Ireland. Journal of Rural Studies, 15(3), 307-315.

DeFilippis, J. (2001). The myth of social capital in community development. Housing Policy Debate, 12(4), 781-806.

Dhesi, A.S. (2000). Social Capital and Community Development. Community Development Journal, 30 (3), 199-214.

Esser, H. (2007). The Two Meaning of Social Capital. In D. Castiglione, J. van Deth, \& G. Wolleb (Eds.), The Handbook of Social Capital (pp. 22-49). New York: Oxford University Press.

Fine, B., \& Lapavitsas, C. (2004). Social Capital and Capitalist Economies. South Eastern Europe Journal of Economics, 1, 17-34.

Fukuyama, F. (1995). Trust: The Social Virtues and the Creation of Prosperity, New York: The Free Press.

Gallardo, R. (2015). Community Economic Development Approaches. Affiliation: Mississippi State University Extension Service, See Discussions, Stats, And Author Profiles for This Publication at: 
https://www.researchgate.net/publication/308079146

Gasper, D. (2010). Understanding the diversity of conceptions of well-being and quality of life, The Journal of Socio-Economics, 39(3), 351-360.

Gómez-Jacinto, L., \& Hombrados-Mendieta, I. (2002). Multiple Effects of Community And Household Crowding. Journal of Environmental Psychology, 22(3), 233-246.

Goldenberg, M. (2008). A Review of Rural and Regional Development Policies and Programs, Ottawa, ON: Canadian Policy Research Networks.

Green, P. G., \& Haines, A. (2002). Asset Building and Community Development, Thousand Oaks, CA: SAGE Publication.

Gutierrez, L.M. (1995). Understanding the Empowerment Process: Does Consciousness Make a Difference? Social Work Research, 19(4), 229-237.

Harriss, J. (2002). Depoliticizing Development: The World Bank and Social Capital, London: Anthem Press.

Helliwell, J., \& Putnam, R. (2004). The Social Context of Well-being, Philosophical Transactions of the Royal Society, London, B, 359: 1435-1446

Hombrados-Mendieta, I., \& Gómez-Jacinto, L. (2001). Empowerment in the community intervention. Available at: https://www.semanticscholar.org/paper/E-m-p-o-w-erment-in-the-community-intervention-Hombrados-Mendieta-G\%C3\%B3mezJacinto/ab01a5c2527cad32b629e1456ae7a17484f5d6b9

Kay, A. (2005). Social capital, the social economy and community development. Community Development Journal, 41(2), 160-173.

Khwaja, A.I. (2004). Is increasing community participation always a good thing? Journal of the European Economic Association, 2(2-3), 427-436.

Labonte, R., \& Laverack, G. (2001). Capacity building in health promotion. Part 1: For whom? And for what purpose? Critical Public Health, 11, 111-127.

Lang, R. E., \& Hornburg, S. P. (1998). What is social capital and why is it important to public policy? Housing Policy Debate, 9(1), 1-16.

Larson, E.C., Luloff, A.E., Bridger, J.C., \& Brennan, M.A. (2015). Community as a mechanism for transcending well-being at the individual social and ecological levels. Community Development Journal, 46(4), 407-419.

Law Number 32 of 2004 on Local Government in Article 213 paragraph (1) states that "The village can establish village owned enterprises in accordance with the needs and potential of the village".

Law Number 6 of 2014 about Indonesia Villages.

Malhotra, A., Schuler, S.R. \& Boender, C. (2002). Measuring Women's Empowerment as a Variable in International Development, Washington DC: The World Bank.

Mansuri, G., \& Rao, V. (2003). Evaluating community-based and community-driven development: A critical review of the evidence working paper. Development Research Group: World Bank.

Mark, T.J. (1998). Rural government and community participation: The planning role of community councils. Journal of Rural Studies, 14(1), 51-62.

McCrea, R., Walton, A., \& Leonard, R. (2014). Conceptual framework for Investigating Community Wellbeing and Resilience. Rural Society, 23(3), 270-282.

Musa, H.D., Yacob, M.R., \& Abdullah, A.M. (2019). Delphi exploration of subjective well-being indicators for strategic urban planning towards sustainable development in Malaysia. Journal of Urban Management, 8, 28-41. 
Narayan, D., \& Shah, T. (2000). Connecting the local to the global: Voices of the poor, Washington, D.C.: World Bank.

Onyx, J., \& Bullen, P. (2000). Measuring Social Capital in Five Communities. The Journal of Applied Behavioral Science, 36(1), 23-42.

Peterson, N.A., \& Hughey, J. (2004). Social cohesion and intrapersonal empowerment: Gender as moderator, Health Education Research, 19(5), 533-542.

Phillips, E.N., Berg, M.J., Rodriguez, C., \& Morgan, D., (2010). A case study of participatory action research in a public New England Middle School: Empowerment constraints and challenges, American Journal of Community Psychology, 46, 179-194.

Poter, A. (1998). Social Capital: Its Origins and Application in Modern Sociology. Annual Review Sociology, 24, 1-24.

Putnam R.D. (1993). The Prosperous Community: Social Capital and Public Life. The American Prospect, 13, 35-42.

Putnam, R.D. (2000). Bowling Alone: the Collapse and Revival of American Community, New York: Simon \& Schuster.

Randall, A. (2010) Multifunctional agriculture: An engine of regional economic growth. APSTRACT: Applied Studies in Agribusiness and Commerce, 4(1-2), 7-15.

Ray, C. (2000). The EU Leader program me: Rural development laboratory. Sociologia Ruralis, 40(2), 163-171.

Ruth, L. (2000). New energies for an old idea: Reworking approaches to 'community' in contemporary rural studies. Journal of Rural Studies, 16(1), 23-35.

Sarjiyanto (2017). Peran Kelompok Masyarakat (KUBE Lumbung Sinergi) Dalam Meningkatkan Kesejahteraan Warga Desa Bulakan Sukoharjo Jawa Tengah. Jurnal Ilmu Ekonomi dan Pembangunan, 17(1), 41-54.

Sally, S. (2008). Are rural development programs socially inclusive? Social inclusion civic engagement participation and social capital: Exploring the differences. Journal of Rural Studies, 24(4), 450-457.

Solano Lara, C., Fernández Crispín, A., \& López Téllez, M.C. (2018). Participatory rural appraisal as an educational tool to empower sustainable community processes. Journal of Cleaner Production, 172, 4254-4262.

Soler, P., Planas, A., Ciraso-Calí, A. \& Ribot-Horas. A. (2014). Empowerment in the Community. The Design of an Open Indicators System from Participatory Evaluation Processes, Pedagogía Social Revista Interuniversitaria, 24 49-77.

Steyaert, P., \& Jiggins, J. (2007). Governance of complex environmental situations through social learning: A synthesis of SLIM's lessons for research, policy and practice, Environmental Science \& Policy, 10(6), 575-586.

Sung, H., \& Phillips, R.G. (2018). Indicators and community well-being: Exploring a relational framework. International Journal of Community Well-Being, 1, 63-79.

Theodori, G.L. (2005). Community and Community Development in Resource Based Areas: Operational Definitions Rooted in an Interactional Perspective, Society dan Natural Resources: An International Journal, 18(7), 661-669.

Trigilia, C. (2001). Social Capital and Local Development. European Journal of Social Theory, 4(4), 427-442.

Winterton, R., Hulme Chambers, A., Farmer, J., \& Munoz, S.-A. (2014). considering the implications of place-based approaches for improving rural community well- 
being: The value of a relational lens, Rural Society, 23(3), 283-295.

Wiseman, J., \& Brasher, K. (2008). Community well-being in an unwell world: trends, challenges, and possibilities. Journal of Public Health Policy, 29, 353-366.

Woolcock, M. (1998). Social Capital and Economic Development: Toward a Theoretical Synthesis and Policy Framework. Theory and Society, 27(2), 151-208.

Zimmerman, M.A. (2000). Empowerment Theory: Psychological, Organizational and

Community Levels of Analysis. (pp, 43-64). Hand book of Community Psychology, edited by Julian Rappaport and Edward Seidman. New York: Kluwer Academic/Plenum Publisher. 